\title{
Adélie penguin population change in the pacific sector of Antarctica: relation to sea-ice extent and the Antarctic Circumpolar Current
}

\author{
P. R. Wilson ${ }^{1, *}$, D. G. Ainley ${ }^{2}$, N. Nur ${ }^{3}$, S. S. Jacobs ${ }^{4}$, K. J. Barton ${ }^{1}$, G. Ballard ${ }^{2}$, \\ J. C. Comiso ${ }^{5}$ \\ ${ }^{1}$ Landcare Research, Private Bag 6, Nelson, New Zealand \\ ${ }^{2}$ H.T. Harvey \& Associates, 3150 Almaden Expressway, Suite 145, San Jose, California 95118, USA \\ ${ }^{3}$ Point Reyes Bird Observatory, 4990 Shoreline Highway, Stinson Beach, California 94970, USA \\ ${ }^{4}$ Lamont-Doherty Earth Observatory, Palisades, New York 10964, USA \\ ${ }^{5}$ Laboratory for Hyrdospheric Processes, NASA-Goddard Space Flight Center, Greenbelt, Maryland 20771, USA
}

\begin{abstract}
One of the longest continuing data sets involving a marine organism in the Antarctic is that of annual estimates of breeding population size of Adélie penguins Pygoscelis adeliae at colonies on Ross Island, Ross Sea, 1959 to 1997. The sizes of these colonies have displayed significant interannual variability during the 29 -yr period. We hypothesized that changes are related to natural environmental factors; and used path analysis to analyze annual variation in population growth in relation to physical environmental factors during that part of the record with comparable sea-ice satellite imagery from 1973 to 1997 . The Ross Sea sector of the Southern Ocean lying north of Ross Island, from $150^{\circ} \mathrm{E}$ to $130^{\circ} \mathrm{W}$, comprised our study area. Annual population growth measured during summer was explained best, and inversely, by the extent of sea-ice in the study area 5 winters earlier, and in some way related to the Southern Oscillation. Analysis of a subset of the sea-ice data from 1979 to 1997 indicated strong correlations to ice conditions in the eastern portion of the study area (174 to $\left.130^{\circ} \mathrm{W}\right)$, and virtually no correlations to the western half $\left(150^{\circ} \mathrm{E}\right.$ to $\left.175^{\circ} \mathrm{W}\right)$. This result supported other indirect evidence that the Ross Island penguins winter in the eastern Ross Sea/western Amundsen Sea. A demographic model indicated that variation in survival of juveniles and subadults might account for the observed population variation, and would also explain the 5-yr lag as $5 \mathrm{yr}$ is the average age of recruitment to the summer breeding population. Extensive sea-ice during winter appears to reduce subadult survival, expressed subsequently when these cohorts reach maturation. We hypothesize that extensive (more northerly) sea-ice limits access of penguins to productive waters known to occur south of the southern boundary of the Antarctic Circumpolar Current, with starvation or increased predation disproportionately affecting less-experienced birds. The observed patterns of penguin population change, including those preceding the satellite era, imply that sea-ice extent has changed significantly over recent decades.
\end{abstract}

KEY WORDS: Adélie penguin · Population regulation - Sea-ice extent · Southern Oscillation · Antarctic Circumpolar Current $\cdot$ Climate change $\cdot$ Ross Sea $\cdot$ Pygoscelis adeliae

\section{INTRODUCTION}

Population dynamics of the Adélie penguin Pygoscelis adeliae are sensitive to Antarctic climate, an ob-

\footnotetext{
*E-mail: wilsonpr@landcare.cri.nz
}

servation made by geologists, glaciologists, and paleontologists, as well as marine biologists (Baroni \& Orombelli 1994, Emslie 1995, Smith et al. 1999). The species is an obligate associate of sea-ice (Ribic \& Ainley 1988/ 1989, Ainley et al. 1994), which constitutes a major marine habitat. Indeed, at maximal extent reached during winter, Antarctic sea-ice covers $40 \%$ of the 
Southern Ocean and $6 \%$ of the World Ocean (Gloersen et al. 1992). In addition to seasonal change, ice extent fluctuates markedly at annual and longer periods (Jacobs \& Comiso 1989, 1993, Stammerjohn \& Smith 1997, Smith et al. 1999) and affects the natural-history patterns of marine organisms, including Adélie penguins and their prey (Fraser et al. 1992, Kawaguchi \& Satake 1994, Siegal \& Loeb 1995, Trathan et al. 1996, Loeb et al. 1997).

Decreased prevalence of sea-ice along the west coast of the Antarctic Peninsula (Weatherly et al. 1991, Jacobs \& Comiso 1993, Stammerjohn \& Smith 1997) has led to decreased populations of Adélie penguins in that area (Smith et al. 1999). Therefore, we hypothesized that changes in sea-ice should also help to explain variations observed in population size of Adélie penguins in the Ross Sea sector. The annual assessment of Adélie population size at colonies on Ross Island, Ross Sea, from 1959 to 1997 (Taylor \& Wilson 1990, Taylor et al. 1990, additional data contained herein) is one of the longest-running marine biological time series in the Antarctic. It should be noted that the Ross Island penguin data series predates that of the satellite-derived sea-ice record. Thus, if a link does exist between Adélie penguins and sea-ice extent, understanding the environmental factors that affect penguin populations may facilitate understanding climate change during the past $40 \mathrm{yr}$ in the Southern Ocean.

The variability in sea-ice extent is linked both to local, direct factors, such as surface temperature and wind (White \& Peterson 1996, Jacobs \& Comiso 1997, Jacobs \& Giulivi 1998), and to remote, indirect factors, that may be related to or affected by the Southern Oscillation (SO) and Antarctic Circumpolar Wave (ACW) (White \& Peterson 1996, Jacobs \& Comiso 1997, Bromwich et al. 1998, Gloersen \& Mermicky 1998, Peterson \& White 1998, Mayewski \& Goodwin 1999). Here we use path analysis and demographic modeling to relate population change in Adélie penguins to environmental factors either directly important to the penguins (Fraser et al. 1992, Trathan et al. 1996) or known to interact with such factors (e.g., SO, ACW).

Our study area included the Ross Sea, where 30\% of the world population of Adélie penguins reside (Woehler 1993), and waters to the north in the Pacific (Ross Sea) sector of the Southern Ocean (Fig. 1), $150^{\circ} \mathrm{E}$ to $230^{\circ} \mathrm{E}\left(130^{\circ} \mathrm{W}\right)$. On the basis of indirect evidence, we think Adélie penguins that breed on Ross Island winter in the northeastern portion of our study area. Ainley et al. (1984) report high densities of Adélie penguins at the end of the nesting season (February) swimming from the vicinity of large Ross Island nesting colonies (southwestern Ross Sea) northeastward toward an area of late-summer sea-ice in the eastern Ross Sea. Ainley et al. $(1984,1998)$ also report high densities of Adélies in that area of persistent pack ice in that season. Those densities cannot be explained by the very few and tiny colonies that exist along the eastern Ross Sea and western Amundsen Sea coasts (cf. at-sea densities in Ainley et al. 1984, 1998; colony sizes in Woehler 1993). Observations also indicate that Adélie penguins, being visual predators (Wilson et al. 1993), winter in the pack ice where there is daylight (Falla 1937), and where ice concentration is between 15 and $80 \%$ cover (Ainley et al. 1993, 1994). Therefore, we also looked at regional differences in sea-ice within the confines of our study area.
Fig. 1. Study area, shaded. Position of the ice edge during September 1985 (year of most northerly maximum extent) and September 1986 (year of most southerly maximum, within the 1979 to 1997 period) shown by medium broken lines (from Gloersen et al. 1992). Note that the $15 \%$ ice-cover boundary is depicted. Southern boundary of the Antarctic Circumpolar Current (ACC) shown by heavy broken line (from Orsi et al. 1995). Heavy line indicates approximate mean position of Antarctic Polar Front (from Moore et al. 1999) 


\section{METHODS}

Data selection. We used colony and other data only from 1973 when assessment of sea-ice using satellite imagery began (see below). Penguin population sizes were derived from ground counts and/or aerial photos acquired on or about December 1, each year (end of egg laying) at Cape Royds $\left(77^{\circ} 34^{\prime} \mathrm{S}, 166^{\circ} 11^{\prime} \mathrm{E}\right)$ and Cape Bird $\left(77^{\circ} 13^{\prime} \mathrm{S}, 166^{\circ} 28^{\prime} \mathrm{E}\right)$, Ross Island, in the southwestern Ross Sea. Comparisons of these methods and population for the years 1968 to 1987 have been published previously (Taylor \& Wilson 1990, Taylor et al. 1990). For the years from 1988 to 1997, the population data are presented here for the first time.

Surface air temperatures, taken daily at Scott Base, Ross Island, were provided by the New Zealand National Institute of Water and Atmospheric Research. Meridional wind [NOAA NCEP-NCAR CDAS-1 monthly intrinsic pressure level] for the Ross Sea ( 65 to $78^{\circ} \mathrm{S}, 160$ to $230^{\circ} \mathrm{E}$ ), and the SOI were obtained from the Lamont Climate Group Data Library (http://rainbow.ldeo.columbia.edu). Satellite passive microwave data on sea-ice extent (area of ocean surface with ice concentration $>15 \%$ ) and seaice concentration for the Ross Sea sector, 150 to $230^{\circ} \mathrm{E}$, during the period from 1979 to 1997 were derived from passive microwave data using the bootstrap algorithm (Comiso et al. 1997). Gaps were filled from the national ice center tabulations as described by Jacobs \& Giulivi (1998; e.g., from 1973 to 1978). We conducted analyses both with and without the 1973 to 1978 segment of seaice data, as the sea-ice sensor differed from that used in subsequent years. The sea-ice data set of 1979 to 1997 was further separated into western $\left(150^{\circ} \mathrm{E}\right.$ to $\left.175^{\circ} \mathrm{W}\right)$ and eastern $\left(174^{\circ}\right.$ to $\left.130^{\circ} \mathrm{W}\right)$ portions, with comparisons made with average monthly ice extent and average monthly latitude relative to the 15 and $80 \%$ ice-cover boundaries.

For comparison with the penguin data, we calculated monthly averages of daily values from the above data sets. The following parameters were then used as independent variables in the regression analyses detailed below: maximum and minimum ice extent; maximum and minimum ice area (ice extent minus the open water between ice floes); maximum ice concentration $(\%)$; ice range \#1 (change in ice extent from the maximum preceding the penguin breeding season to the minimum following), ice range \#2 (change in ice concentration from the minimum following the breeding season to the subsequent maximum); month of the maximum ice extent before the breeding season; number of months during which ice concentration was within $10 \%$ of the maximum; and average ice concentration during the months of maximum ice growth (March to May). We also calculated annual average ice extent, and annual and quarterly average values for wind speed, air temperature and southern Oscillation Index (SOI). Finally, as noted above, we looked at relationships to monthly averages of ice extent and northernmost latitude in the eastern and western portions of the study area using the 15 and $80 \%$ ice-cover boundaries. For the above parameters, it should be noted that (1) minimum ice extent always occurs during February, after a given penguin breeding season; (2) maximum extent occurs sometime between July and October, before a given penguin breeding season; and (3) the penguin breeding season occurs from late October to early February.

Statistical and demographic analysis. The dependent variable for statistical analysis was annual population growth rate expressed as $\lambda=N(t+1) / N(t)$, where $N$ is population size at Cape Bird or Cape Royds, and $t$ is year. We used simple regression analyses to identify candidate variables for inclusion in the path analyses. The latter identified causal relationships among the independent variables (Sokal \& Rohlf 1995). Once we had identified a causal model with 2 independent variables (listed above), we confirmed that the model could not be further simplified by dropping a variable, and that no other combination of 2 independent variables provided better explanatory power than the chosen model using the criterion of maximizing adjusted $R^{2}$ (Neter et al. 1990). We also confirmed that no additional independent variables contributed significantly to the statistical model, given the inclusion of the first 2 dependent variables.

We log-transformed independent variables where this improved normality of residuals and/or linearized the relationship of dependent and independent variables (consistent with assumptions of path analysis). To illustrate results from path analysis, we display standardized, partial regression coefficients, symbolized $b$ (i.e., standardized to maximum of 1.0, minimum of -1.0) (Sokal \& Rohlf 1995), together with their standard errors.

To evaluate the sensitivity of Adélie penguin population growth rate to changes in demographic parameters, we constructed Leslie population projection matrix models (Caswell 1989). We developed a 'prebreeding census' model, one which produced a stable population, based on a synthesis of published and unpublished values. Reproductive success was estimated from our current studies on this population (data from 1997 to 2000); age-specific proportion of individuals breeding was taken from Ainley et al. (1983). Adult survival was based on values reported by Ainley et al. (1983), but adjusted upwards by a small amount to produce $\lambda=1.00$. Survival of immatures (individuals in their first, second, and third year of life) was scaled relative to adult survival, on the basis of studies of other seabirds with similar life-history patterns (Nur \& Sydeman 1999). 
We evaluated sensitivity of population parameters in 2 ways. In the first approach, we altered 1 parameter at a time [reproductive success among breeding individuals; adult survival; first-year survival (to age $12 \mathrm{mo}$ ); second-year survival; and third-year survival]; and determined the absolute and relative change needed to increase or decrease $\lambda$ by $1 \%$ (i.e. change from 1.00 to 1.01) for that 1 parameter. In the second approach, we calculated elasticity (Caswell 1989) for each element of the Leslie matrix using RAMAS GIS 2.0 (Akcakaya 1997). Elasticity values present the proportionate contribution of changes in each element (or combination of elements) to changes in $\lambda$.

\section{A}

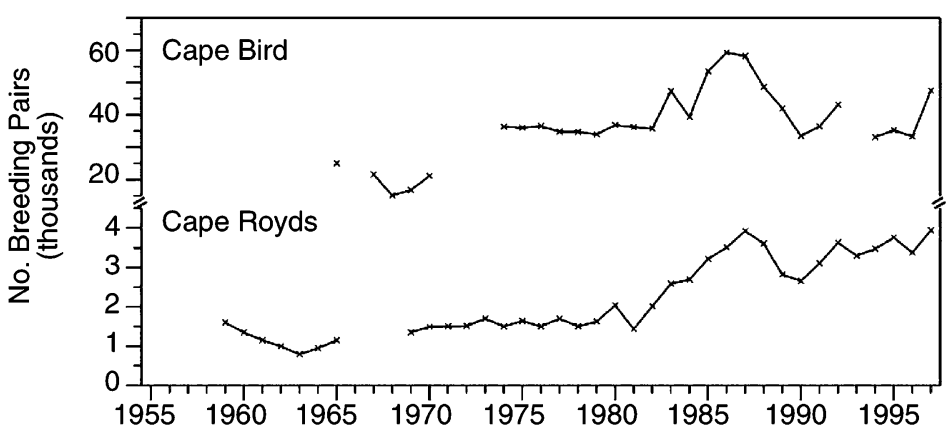

B

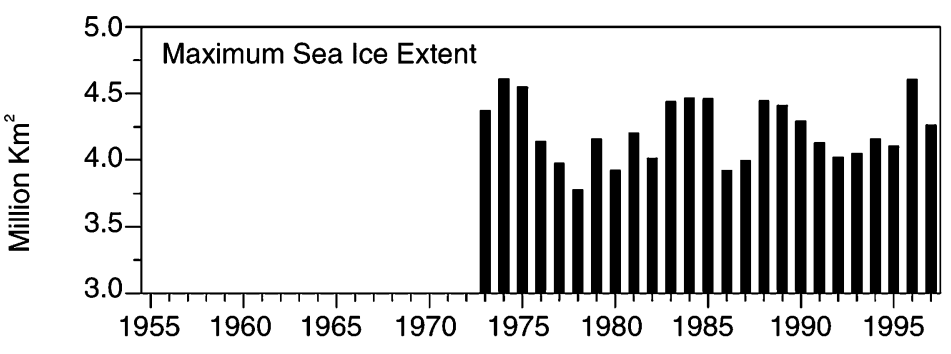

C

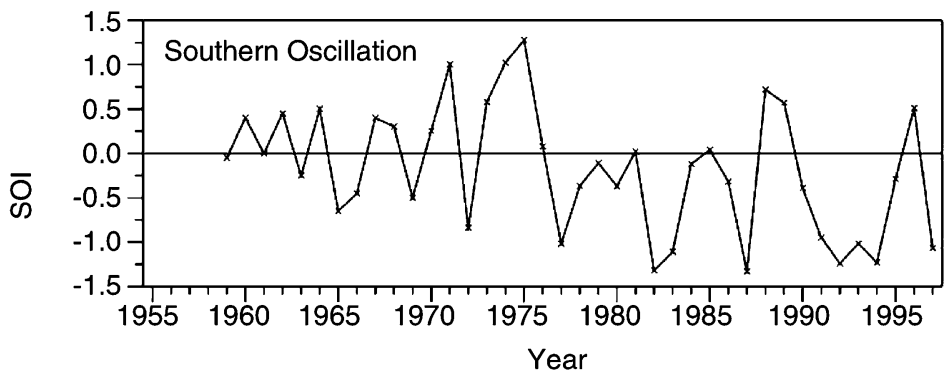

Fig. 2. (A) Breeding pairs of Adélie penguins at Cape Bird $\left(77^{\circ} 13^{\prime} \mathrm{S}\right.$, $\left.166^{\circ} 28^{\prime} \mathrm{E}\right)$ and Cape Royds $\left(77^{\circ} 34^{\prime} \mathrm{S}, 166^{\circ} 11^{\prime} \mathrm{E}\right)$ on Ross Island from 1959 to 1997 (note different vertical scales). (B) Monthly average sea-ice extent (area with ice concentration $>15 \%$ from satellite passive microwave data) for the winter/spring month (July to October) in which maximum ice cover was reached in the Ross Sea sector (150 to $\left.230^{\circ} \mathrm{E}\right)$ from 1973 to 1997 . (C) Southern Oscillation Index (annual average) from 1959 to 1997

\section{RESULTS}

\section{Population change}

The Adélie penguin population was stable at relatively low numbers through the 1960s, but began to increase substantially by the late 1970s (Fig. 2A). The change was more evident at Cape Royds than Cape Bird. Further increases through the mid-1980s raised these populations to levels 3 times those in the 1960s. The populations then dipped steeply in the late 1980s, followed by renewed but fluctuating growth, especially at Cape Royds. All 34 Ross Sea colonies changed in a similar fashion (Taylor et al. 1990), a pattern that argues for a common explanatory factor.

\section{Environmental factors}

Path analysis (Sokal \& Rohlf 1995; see 'Methods') identified various factors that might influence Adélie penguin population dynamics in the Ross Sea. Proximal mechanisms included variation in reproductive success, breeding propensity (proportion of adults that breed), adult survival, firstyear (juvenile) survival and subadult (i.e. immature; second-year, third-year) survival (see below). Ultimate mechanisms included the effects of the environmental variables noted above. A preliminary analysis indicated that maximum ice extent (across the entire study area; Fig. 2B) had the most significant effect on the dependent variable: Adélie penguin population growth (size in year $t+1$ relative to year $t$ ) for both colonies (Table 1 )

In the analyses, we considered lags of 1 to $8 \mathrm{yr}$ on the dependent variable. An environmental or ice variable that correlated with population growth having a lag of 0 or 1 yr would suggest a factor related to adult survival or breeding propensity. A variable having a lag of 3 to 7 yr would implicate factors that influence juvenile or subadult survival, since recruitment of a given cohort occurs over that period of time (Ainley et al. 1983, p. 183-197). See below for further discussion of these points.

The best single predictor of Adélie penguin population growth proved to be monthly maximum ice extent 5 yr earlier (Table 1). That is, size in year $t+5$ compared with $t+4$ was correlated with ice extent in year $t$ for both the Cape Royds and Cape Bird populations $(b=-0.525, \mathrm{p}<0.001$; Fig. 3A). No significant relationship was evident between maximum ice extent in year $t$ and population growth from year $t-1$ to year $t$.

We also investigated the relationship of other environmental parameters to Adélie penguin pop- 
ulation growth. The environmental variables were lagged 0,1 , or 2 yr relative to maximum ice extent, itself lagged $5 \mathrm{yr}$ relative to population growth. In the model most consistent with the data (Fig. 4A), only annual average SOI (Fig. 2C) in year $t$ correlated significantly with maximum ice extent in year $t(b=0.630, \mathrm{p}<0.001)$, which in turn influenced population growth in year $t+5$ relative to year $t+4$. The correlation of SOI with annual changes in population size is, thus, indirect, mediated by maximum ice extent. We contrasted the preferred model with an alternative model (Fig. 4B), which incorporates the additional, direct effect of SOI in year $t$ on population growth in year $t+5$, relative to the previous year. This direct effect is weak and insignificant $(b=0.228, \mathrm{p}>0.2)$. With the inclusion of both maximum ice extent and SOI in the statistical
Table 1. Standardized regression coefficients between population growth rate (population size in year $t$ compared to year $t-1$ ) and candidate explanatory variables for various time lags. Explanatory variables are ranked in order of betas; 12 variables with greatest betas are shown. Twenty-four explanatory variables (with variable time lags, from 0 to $8 \mathrm{yr}$ ) were examined in all: 9 ice variables, 5 SOI variables, 5 wind speed variables, and 5 air temperature variables; see 'Methods'. Data are from 1973 to 1997 data set; both colonies combined in the analysis. Coefficient values shown are for an effect common to the 2 colonies (i.e. betas control for a colony 'main effect'). Number of observations $=$ number of yr of data for each of the 2 colonies. $p$-value is the nominal, a priori $\mathrm{p}$-value (i.e. no post hoc, Bonferonni-type corrections have been made)

\begin{tabular}{|lrcc|}
\hline Explanatory variable & Coefficient & $\mathrm{p}$-value & $\mathrm{n}$ \\
\hline Maximum ice extent, year $t-5$ & -0.523 & $<0.001$ & 38 \\
Meridional wind, Oct to Dec quarter, year $t-6$ & -0.494 & $<0.01$ & 36 \\
SOI Apr to Jun quarter, year $t$ & -0.476 & $<0.01$ & 46 \\
Ice extent, Mar to May mean, year $t-2$ & -0.471 & $<0.01$ & 44 \\
Meridional wind, annual (calendar yr) mean, year $t-6-0.468$ & $<0.01$ & 36 \\
SOI, annual (calendar yr) mean, year $t$ & -0.456 & $<0.01$ & 46 \\
Month of ice extent max (Jan $=1$, Feb $=2$, etc.) & -0.456 & $<0.01$ & 45 \\
Change in ice extent (max year $t-$ min year $t+1$ ), & +0.445 & $<0.01$ & 42 \\
year $t-3$ & -0.441 & $<0.01$ & 38 \\
Ice extent, Mar to May mean, year $t-5$ & -0.407 & $<0.01$ & 42 \\
Air temperature, Jan to Mar quarter, year $t-3$ & +0.387 & $<0.05$ & 36 \\
SOI Jan to Mar quarter, year $t-6$ & -0.384 & $<0.05$ & 38 \\
Average ice extent (calendar year), year $t-5$ & & & \\
\hline
\end{tabular}
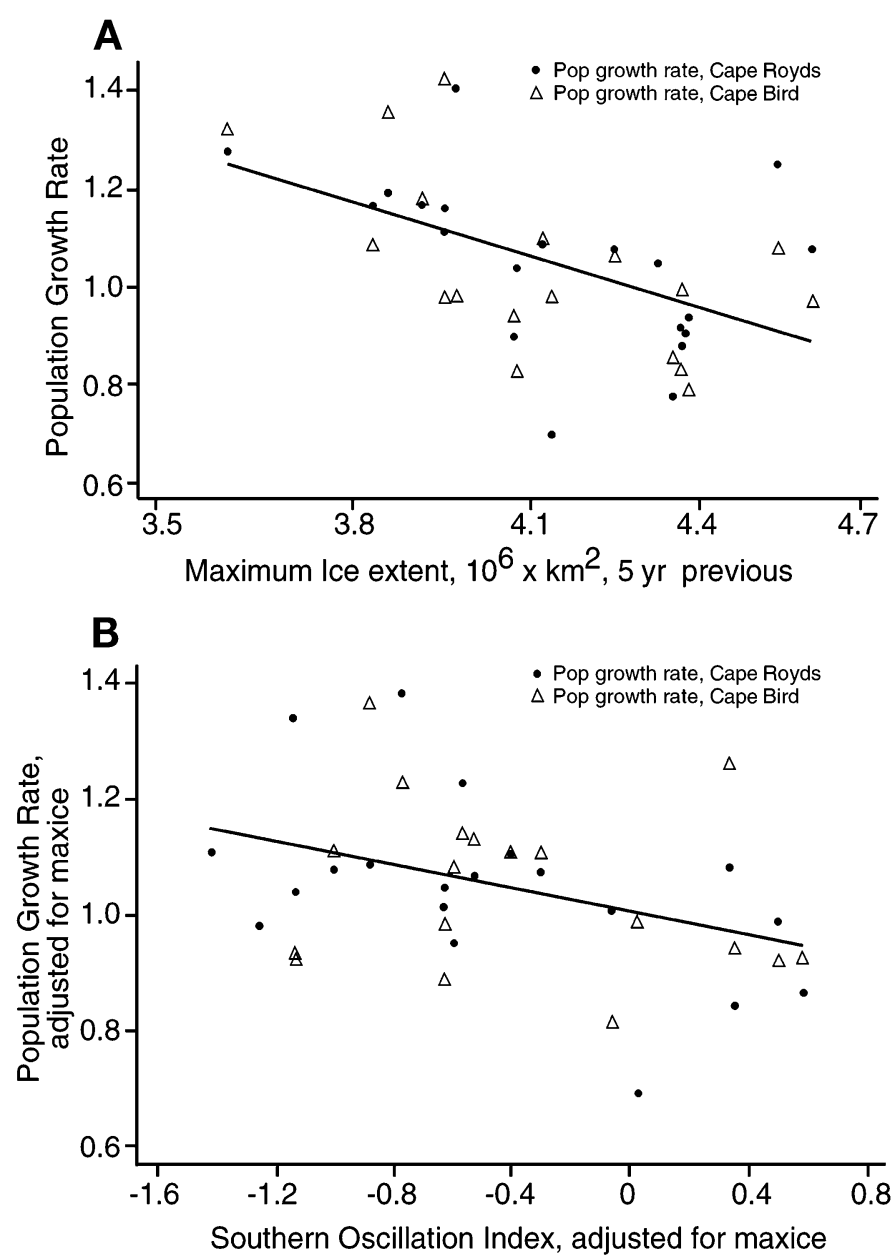

model, no other ice or environmental variable made a significant contribution to explaining variation in population growth. The Fig. 4A-model was also confirmed (and preferred) when ice extent data were restricted to the years 1979 to 1997, during which multi-channel satellite sensors provided more accurate data than were available in 1973 to 1978 . In other words, the same result ensued regardless of whether the longer or shorter time series of ice data were used.

Finally, we found a close relationship between maximum ice extent and the amount of ice, expressed as ice area, in the 1979 to 1997 data set $(r=0.9512, \mathrm{p}<$ 0.001). This parameter is a measure of ice pack consolidation, i.e. the relative distribution of ice and open water (leads between floes). In the regression model, ice area disappeared from the result, owing to its high degree of co-variance with ice extent. However, it could still be a variable important to Adélie penguins (see below).

Fig. 3. Adélie penguin population growth rate at Cape Royds and Cape Bird, Ross Island from 1973 to 1997. For each panel, a single least-squares line of best fit is depicted, fitting a common slope for both colonies. (A) Population change (population size at time $t$ /population size at time $t-1)$ in relation to monthly maximum ice extent 5 yr earlier $(b=-0.525+0.144$; $\mathrm{p}<0.001$ ); (B) Population change in relation to SOI in current year $(b=-0.373+0.151 ; \mathrm{p}=0.018)$, both variables statistically controlled for maximum ice extent $5 \mathrm{yr}$ earlier (effect of maximum ice extent $5 \mathrm{yr}$ earlier on population growth rate: $b=-0.348, \mathrm{p}=0.027$ ) 
A

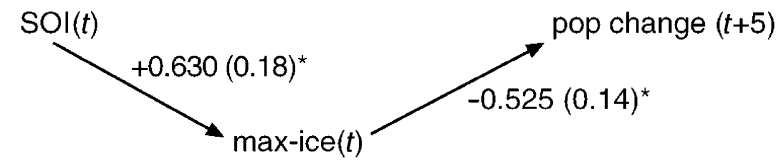

B

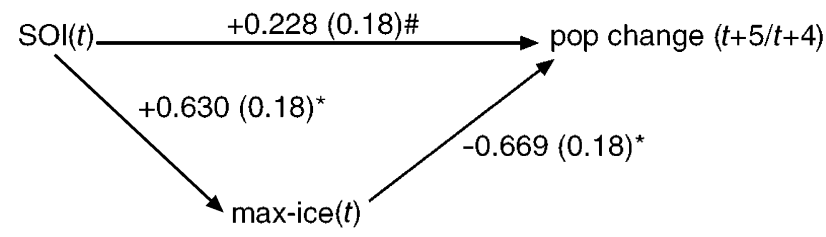

Fig. 4. Two causal models identified by path analysis. Shown are the standardized regression coefficients, $b$ with SE in parentheses. Arrows indicate causal pathways; \#: $p>0.2{ }^{*}{ }^{*} p<0.001$. (A) Model favored by path analysis: parsimonious and consistent with the data, in which there is an effect of SOI on maximal ice extent and an effect of maximal ice extent on population growth rate 5 yr later; (B) Alternative model in which there is a direct effect of SOI on population change, in addition to the pathway identified in A

\section{Demographic factors}

Results from the sensitivity analysis (Table 2) demonstrate that population dynamics are most sensitive to small changes in adult survival. Much larger, relative changes in other parameter values are required to produce even a $1 \%$ change in population growth rate. Elasticity results confirm this pattern: elasticity values for adult survival (all age classes) sum to 0.811, while

Table 2. Increase in a single demographic parameter (rate) required to increase annual population growth rate $(\lambda)$ from 1.00 to 1.01 . A decrease in parameter values by the same relative amount will produce a decrease in lambda from 1.00 to 0.99

\begin{tabular}{|c|c|c|c|}
\hline Demographic rate & $\begin{array}{l}\text { Original } \\
\text { value }^{a}\end{array}$ & $\begin{array}{c}\text { New } \\
\text { value }^{\mathrm{b}}\end{array}$ & $\begin{array}{l}\text { Relative change } \\
\text { in value }(\%)\end{array}$ \\
\hline Adult survival & 0.918 & 0.929 & 1.2 \\
\hline Reproductive success & 1.280 & 1.426 & 11.4 \\
\hline 1st yr survival & 0.4 & 0.4456 & 11.4 \\
\hline 2nd yr survival & 0.6734 & 0.7503 & 11.4 \\
\hline 3rd yr survival & 0.6734 & 0.7503 & 11.4 \\
\hline \multicolumn{4}{|c|}{$\begin{array}{l}\text { a'The combination of parameter values in this column will } \\
\text { produce a population with a stable growth rate }(\lambda=1.00 \text { ), } \\
\text { assuming that breeding propensity is } 0.09,0.30,0.52 \text {, } \\
0.73,0.85 \text {, and } 0.87 \text { for } 3,4,5,6,7 \text {, and } 8+\text { yr olds, respec- } \\
\text { tively (from Ainley et al. 1983). For derivation of other } \\
\text { parameter values see 'Methods' } \\
\text { b Changing to } 1 \text { and only } 1 \text { of these parameter values (with } \\
\text { others as in 'Original' values) will produce a population } \\
\text { with a growth rate of } 1.01\end{array}$} \\
\hline
\end{tabular}

elasticity for second and third-year survival $=0.063$, as does first-year survival combined with reproductive success. It is not possible to calculate separate elasticity values for first-year survival and reproductive success since they are combined as a single element in the population projection matrix (Caswell 1989). A sensitivity analysis of demographic variables in the population that breeds in the southern Ross Sea indicates that Adélie penguin population size would be most easily changed by variation in adult survival rate (Table 2). The steep decline in population size in the late 1980s, from which the Cape Bird colony had not recovered by 1997, is most parsimoniously accounted for by a shortterm drop in adult survival. At the same time, there is potential for an important role of changes in juvenile and subadult survival in explaining population fluctuations (Blackburn et al. 1991). A relatively small change in first-year (juvenile) survival (from 0.40 to 0.446) can produce a $1.0 \%$ change in population growth (or decline); a change in juvenile survival from 0.40 to 0.55 (not inconceivable) can produce a $3.0 \%$ change in population growth, as can a change of juvenile survival from 0.40 to 0.26 .

Regular observations at the Ross Island colonies have not revealed any substantial perturbations in either annual survival of adults at those sites or in reproductive success. However, the entire population is believed to winter in the outer ice pack (eastern Ross Sea), where ice concentration is stable but not compacted and daylight is available to make feeding easier (see 'Introduction'). These and the above results suggest a population control factor operating at that time of year consistent with conclusions independently derived from long-term demographic data and analysis. In that regard, Ainley et al. (1983, p. 209-210) noted that most adult and subadult (of those subadults that visit the colony) mortality occurred during the nonbreeding season (February to mid-October) compared with the breeding season (October to January). We did not find a significant correlation between population growth rate with lags of 0 and 1 yr compared with ice extent in the current or previous year. Therefore, this argues against ice extent influencing adult survival or breeding propensity. The actual month in which maximal ice extent was achieved (sometime between July and October) in any given year was not correlated with population growth. From this we infer that population change is independent of whether the maximum is achieved earlier or later in the winter.

Variation in juvenile and/or subadult survival is not the only pathway by which population growth is related to the tested variables examined. Allowing for the 5-yr lagged effects noted above, there is also a significant correlation with SOI in the current year on current population growth ( $b=-0.373, \mathrm{p}=0.018$; Fig. $3 \mathrm{~B})$. 
This second pathway reflects either variation in breeding propensity among adults, or variation in adult survival. As annual average SOI becomes more negative, population size becomes greater compared with the previous year. The effect of maximum ice extent $5 \mathrm{yr}$ earlier, while controlling for the effect of SOI in the current year, is also significant $(p=0.027)$.

\section{Western versus eastern region}

We separated the study area (and the sea-ice data set) into western and eastern portions from 1979 to 1997 (see Methods). Annual change in penguin colony size correlated significantly in the eastern portion of the Ross Sea sector, still with the 5-yr time lag, using the $80 \%$ ice boundary: sea-ice extent $(b=-0.733$, $\mathrm{p}<0.0001)$ and average latitude of the boundary ( $b=$ $0.719, p=0.0001)$. In both cases $p<0.001$. As expected, the relationships to latitude and ice extent are opposite in sign. In contrast, in the western portion and regardless of 5-yr or other time lags, population growth correlated neither with ice extent $(b=-0.094$ for 5-yr lag, $\mathrm{p}>0.6)$ nor latitude $(b=0.046, \mathrm{p}>0.08)$. These results point out the greater ecological significance of ice extent specifically in the eastern portion of the study area, consistent with earlier evidence, as noted above (e.g., the wintering area of the penguins; see 'Introduction').

\section{DISCUSSION}

The negative correlation between Adélie population growth and maximum winter/spring sea-ice extent in the Ross Sea region does not account for all the interannual variability displayed in Fig. 2A. But how is the observed correlation accounted for? Adélie penguins winter south of the unstable ice edge $(<15 \%$ cover $)$, but north of the consolidated pack ( $>80 \%$ cover; Ainley et al. 1993, 1994, 1998). In the eastern portion of our study area, the average latitude of the $15 \%$ ice-cover boundary during maximal annual ice extent ranged from 60.6 to $63.8^{\circ} \mathrm{S}$ (Fig. 1), compared with 62.7 to $65.2^{\circ} \mathrm{S}$ for the $80 \%$ ice-cover boundary. Therefore, suitable wintering habitat is only a couple of hundred kilometers wide, at most (cf. Gloersen et al. 1992). Such a narrow band of Adélie penguin wintering habitat was observed directly on surveys in the Weddell Sea (Ainley et al. 1994). We hypothesize that a more northerly position of this wintering habitat would move Adélie penguins north of the food-rich waters that occur south of the Antarctic Circumpolar Current (cf. Fig. 1, and data summarized in Tynan 1998; see also Nicol et al. 2000). The southern boundary of the ACC lies between 59 and $64^{\circ} \mathrm{S}$ in the eastern portion of our study area (Fig. 1).
More extensive and consolidated ice (with fewer and narrower leads between floes) at maximal ice extent would restrict penguin access to food, with starvation disproportionately affecting younger cohorts.

Alternatively or in addition, the predatory leopard seal Hydrurga leptonyx would also be shifted north with the penguins. This seal has a broad diet, including euphausiids, fish, other seals, and penguins (e.g., Oritsland 1977). In one study where both krill and Adélie penguins were abundant, the seal ignored the penguins (Hofmann et al. 1977), but if krill and fish were not available, the seals might turn more to penguins as a food source. The young, inexperienced penguins would more likely be taken first. Among Adélie penguins, evidence indicates that through experience young birds do attain greater skill at foraging effectively (Ainley \& Schlatter 1972). One reason they require an average 5 yr to begin to breed, may in part, be to hone foraging skill sufficiently to survive the rigors of feeding themselves and chicks and avoiding seals (Ainley et al. 1983, p. 198-206). Finally, more ice (and snow) cover would also limit light penetration to the water column, and could alter the sub-ice environment so that fewer prey might be associated with the underside of the ice. For example, deepening the mixed layer could affect primary production in summer (Smith \& Sakshaug 1990, p. 492-496), and thereby increase the energy required by penguins to access prey concentrated near a deeper pycnocline. A deeper pycnocline has been attributed to heavier sea-ice cover at times in the southern Ross Sea (Jacobs \& Giulivi 1998). Much more research is required to elucidate the relationship between sea-ice extent and the position (southern boundary) and strength of the ACC, as well as the relationship of this interaction to Adélie penguin life history (i.e. the winter-time ecology of this species).

An important aspect of the negative correlation between winter/spring maximum sea-ice extent and Adélie penguin population growth in the Ross Sea $5 \mathrm{yr}$ later is that it appears contradictory to the response of Adélie penguins breeding at the periphery of the seaice zone north and west of the Antarctic Peninsula. There, much discussion has arisen concerning penguin population changes (Fraser et al. 1992, Trathan et al. 1996, Smith et al. 1999). However, the ice-obligate Adélie penguins can also be negatively affected by too little ice (e.g., Ainley et al. 1994, Smith et al. 1999). West of the Antarctic Peninsula extensive ice (but still $<80 \%$ cover) during the winter immediately preceding a breeding season leads to an increase in population size, and less ice to a population decrease. The western Peninsula region has experienced the largest coastal climate change in the Southern Ocean over the last 4 decades, including decreasing extent of winter and spring sea-ice (Weatherly et al. 1991, Jacobs \& Comiso 
1993, 1997, Stammerjohn \& Smith 1997, Comiso 2000). The loss of ice explains the decrease in Adélie penguins observed there.

In addition to the penguin sea-ice relationship, a relationship has also been identified between winter/ spring sea-ice and recruitment of larval Antarctic krill Euphausia superba, an important penguin (and leopard seal) prey. In waters overlying the continental slope, larval krill are upwelled into near-surface waters where more extensive winter sea-ice favors krill recruitment and survival (Ichii 1990, Kawaguchi \& Satake 1994, Loeb et al. 1997). A positive relationship between the ACW (White \& Peterson 1996) and krill year-class strength has been described for waters off the northwest coast of the Antarctic Peninsula mediated by variability in ice extent (Fraser \& Hoffman pers. comm.). When ice cover is meager in winter/spring, krill survival and recruitment are poor. In the Ross Sea region (and for that matter, most of the circumpolar sea-ice zone), where pack ice covers the slope region every winter, no such variation should be evident.

Finally, it is likely that the SOI connection is expressed through variation in ice extent, a relationship discussed elsewhere (Gloersen \& Mermicky 1998, Petersen \& White 1998, Simmonds \& Martinson 2000). Ice extent, in turn, could relate to other factors important to penguins, given the appearance of an SOI connection to population growth, independent of ice extent (Fig. 3B). Ice extent is important for survival of juvenile and subadult penguins, but there is no evidence that it is affecting adult survival or breeding propensity. In our analysis it was interesting that SOI related to ice extent in the eastern but not the western portion of our study area. This may be related to observations that the sea-ice edge in the central-eastern Pacific sector is more responsive to extrapolar climate variability (e.g., Yuan \& Martinson 2000).

In light of the results reported here, the fact that the Ross Island Adélie penguin breeding population was smaller during the late 1950s to early 1970s suggests that ice extent in the region during winter could have been greater at that time. This interval precedes the satellite era, and mostly follows the period during which whaling records have suggested that from October to April pack-ice extent was substantially greater in the Southern Ocean (de la Mare 1997). Further studies are needed to confirm both of these apparent iceecosystem correlations.

Acknowledgements. We thank C. Adams, M. Beigel, I. Gaffney, D. Hardesty, S. Heath, M. Hester, B. Karl, H. Nevins, N. Polish, J. Rees, C. Ribic, B. Thomas, S. Townsend, S. Webb, and S. Zador, for assistance with this project. Logistic support was provided by Antarctica New Zealand and the US Antarctic Program. Financial support was provided by US National
Science Foundation grant (OPP 9526865), by the NASA Polar Program, and by the NZ Foundation for Research, Science, and Technology (CO 9527).

\section{LITERATURE CITED}

Ainley DG, Schlatter RP (1972) Chick raising ability in Adélie Penguins. Auk 89:559-566

Ainley DG, LeResche RE, Sladen WJL (1983) Breeding biology of the Adélie penguin. Univ Calif Press, Berkeley

Ainley DG, O'Conner EF, Boekleheide RJ (1984) The marine ecology of birds in the Ross Sea, Antarctica. Ornith Monogr 32:1-97

Ainley DG, Ribic CA, Spear LB (1993) Species-habitat relationships among Antarctic seabirds: a function of physical or biological factors? Condor 95:806-816

Ainley DG, Ribic CA, Fraser WR (1994) Ecological structure among migrant and resident seabirds of the ScotiaWeddell Confluence region. J Anim Ecol 63:347-364

Ainley DG, Jacobs SS, Ribic CA, Gaffney I (1998) Seabird distribution and oceanic features of the Amundsen and southern Bellinghausen seas. Antarct Sci 10:111-123

Akcakaya HR (1997) RAMAS GIS: linking landscape data with population viability analysis (version 2.0). Applied Biomathematics, Setauket, NY

Baroni C, Orombelli G (1994) Abandoned penguin rookeries as Holocene paleoclimatic indicators in Antarctica. Geology $22: 23-26$

Blackburn N, Taylor RH, Wilson PR (1991) An interpretation of the growth of the Adélie penguin rookery at Cape Royds, 1955-1990. NZ J Ecol 15:117-121

Bromwich D, Liu Z, Van Woert ML, Rogers AN (1998) Winter atmospheric forcing of the Ross Sea polynya. In: Jacobs SS, Weiss RF (eds) Ocean, ice and atmosphere: interactions at the Antarctic continental margin. Antarct Res Ser 75, Am Geophys Union, Washington, DC, p 101-134

Caswell, H (1989) Matrix population models. Sinauer Associates, Sunderland, MA

Comiso JC (2000) Variability and trends in antarctic surface temperatures from in situ and satellite infrared measurements. J Climate 13:1674-1696

Comiso JC, Cavalieri DJ, Parkinson CL, Gloersen P (1997) Passive microwave algorithms for sea-ice concentration: a comparison of two techniques. Remote Sens Environ 60: 357-384

de la Mare WK (1997) Abrupt mid-twentieth-century decline in Antarctic sea-ice extent from whaling records. Nature 389:57-60

Emslie SD (1995) Age and taphonomy of abandoned penguin rookeries in the Antarctic Peninsula. Polar Rec 31:409-418

Falla RA (1937) Birds. BANZ Antarc Res Exped, Repts Ser B, II: $1-288$

Fraser WR, Trivelpiece WZ, Ainley DG, Trivelpiece SG (1992) Increases in Antarctic penguin populations: Reduced competition with whales or a loss of sea-ice due to environmental warming? Polar Biol 11:525-531

Gloersen P, Mernicky A (1998) Oscillatory behavior in Antarctic sea-ice concentration. In: Jeffries MO (ed) Antarctic sea-ice: physical processes, interactions and variability. Antarct Res Ser 74:161-171

Gloersen P, Campbell WJ, Cavalieri DJ, Comiso JC, Parkinson CL, Zwally HJ (1992) Arctic and Antarctic sea-ice, 1978-1987: Satellite passive-microwave observations and analysis. NASA SP-511. US Natl Aeron Space Admin, Washington, DC

Hofmann RJ, Reichle RA, Siniff DB, Muller-Schwarze D 
(1977) The leopard seal (Hydrurga leptonyx) at Palmer Station, Antarctica. In: Llano GA (ed) Adaptations within Antarctic Ecosystems. Smithsonian Institution, Washington, DC, p 769-782

Ichii T (1990) Distribution of Antarctic krill concentrations exploited by Japanese krill trawlers and minke whales. Proc NIPR Symp Polar Biol 3:36-56

Jacobs SS, Comiso JC (1989) Sea-ice and oceanic processes on the Ross Sea continental shelf. J Geophys Res 94(C12): 18195-18211

Jacobs SS, Comiso JC (1993) A recent sea-ice retreat west of the Antarctic Peninsula. Geophys Res Lett 20(12): 1171-1174

Jacobs SS, Comiso JC (1997) Climate variability in the Amundsen and Bellingshausen seas. J Climate 10:697-709

Jacobs SS, Giulivi CF (1998) Interannual ocean and sea-ice variability in the Ross Sea. In: Jacobs SS, Weiss RF (eds) Ocean, ice and atmosphere: interactions at the Antarctic continental margin. Antarct Res Ser 75:135-150

Kawaguchi S, Satake M (1994) Relationship between recruitment of the Antarctic krill and the degree of ice cover near the South Shetland Islands. Fisheries Sci 60:123-124

Loeb V, Siegel V, Holm-Hansen O, Hewitt R, Fraser W, Trivelpiece W, Trivelpiece S (1997) Effects of sea-ice extent and krill on salp dominance on the Antarctic food web. Nature 387:897-900

Mayewski P, Goodwin I (1999) Antarctic's role pursued in global climate change. EOS August 31, 1999:398-400

Moore JK, Abbott MR, Richman JG (1999) Location and dynamics of the Antarctic Polar Front from satellite sea surface temperature data. J Geophys Res 104(C2): 3059-3073

Neter J, Wasserman W, Kutner MH (1990) Applied linear statistical models: regression, analysis of variance, and experimental designs, 3rd edn. Irwin, Homewood, IL

Nicol S, Pauly T, Bindoff NL, Wright S, Thiele D, Hosle GW, Strutton PG, Woehler E (2000) Ocean circulation off east Antarctica affects ecosystem structure and sea-ice extent. Nature 406:504-507

Nur N, Sydeman WJ (1999) Survival, breeding probability and reproductive success in relation to population dynamics of Brandt's cormorants Phalacrocorax penicillatus. Bird Study 46(Suppl 5):92-103

Oritsland T (1977) Food consumption of seals in the Antarctic pack ice. In: Llano GA (ed) Adaptations within Antarctic ecosystems. Smithsonian Institution, Washington, DC, p 749-768

Orsi AH, Whitworth T III, Nowlin WD Jr (1995) On the meridional extent and fronts of the Antarctic Circumpolar Current. Deep-Sea Res I 42:641-673

Peterson WB, White RG (1998) Slow oceanic teleconnections linking the Antarctic Circumpolar Wave with the tropical

Editorial responsibility: Otto Kinne (Editor),

Oldendorf/Luhe, Germany
El Niño-Southern Oscillation. J Geophys Res 103(C11): 24573-24583

Ribic CA, Ainley DG (1988/1989) Constancy of seabird species assemblages: an exploratory look. Biol Oceanogr 6: 175-202

Siegel V, Loeb V (1995) Recruitment of Antarctic krill Euphausia superba and possible causes for its variability. Mar Ecol Prog Ser 123:45-56

Simmonds I, Martinson DG (2000) Relationships between the interannual variability of Antarctic sea-ice and the Southern Oscillation. J Climate 8:637-647

Smith RC, Ainley D, Baker K, Domack E, Emslie S, Fraser B, Kennett J, Leventer A, Mosley-Thompson E, Stammerjohn S, Vernet M (1999) Marine ecosystem sensitivity to climate change. BioScience 49(5):393-404

Smith WO Jr, Sakshaug E (1990) Polar phytoplankton. In: Smith WO Jr (ed) Polar oceanography, Part B. Academic Press, Orlando, p 477-526

Sokal RR, Rohlf FJ (1995) Biometry: the principles and practice of statistics in biological research, 3rd edn. WH Freeman, San Francisco

Stammerjohn SE, Smith RC (1997) Opposing Southern Ocean climate patterns as revealed by trends in regional sea-ice coverage. Climate Change 37:617-639

Taylor RH, Wilson PR (1990) Recent increase and southern expansion of Adélie Penguin populations in the Ross Sea, Antarctica, related to climatic warming. NZ J Ecol 14: 25-29

Taylor RH, Wilson PR, Thomas BW (1990) Status and trends of Adélie penguin populations in the Ross Sea region. Polar Rec 26(159):293-304

Trathan PN, Croxall JP, Murphy EJ (1996) Dynamics of Antarctic penguin populations in relation to inter-annual variability in sea-ice distribution. Polar Biol 16:321-330

Tynan CT (1998) Ecological importance of the southern boundary of the Antarctic Circumpolar Current. Nature 392:708-710

Weatherly JW, Walsh JE, Zwally HJ (1991) Antarctic sea-ice variations and seasonal air temperature relationships. J Geophys Res 96(C8):15119-15130

White WB, Peterson RG (1996) An Antarctic circumpolar wave in surface pressure, wind, temperature and sea-ice extent. Nature 380:699-702

Wilson RP, Peutz K, Bost CA, Culik BM, Bannasch R, Reins T, Adelung D (1993) Diel dive depth in penguins in relation to diel vertical migration of prey: whose dinner by candlelight? Mar Ecol Prog Ser 94:101-104

Woehler EJ (1993) The distribution and abundance of Antarctic and subantarctic penguins. Sci Comm Antarc Res, Scott Polar Res Inst, Cambridge

Yuan X, Martinson DG (2000) Antarctic sea-ice extent variability and its global connectivity. J Climate 13:1697-1717

Submitted: April 11, 2000; Accepted: December 8, 2000

Proofs received from author(s): March 16, 2001 